\title{
Women's Political Participation in Legislative Process of Regional House of Representative at Karawang District Period 2009-2014
}

\author{
Eka Yulyana \\ Doctorate Program in Administration Science, Padjadjaran University \\ Lecturer in Department of Governmental Science \\ State University of Singaperbangsa \\ Karawang, Indonesia \\ e.yulyana@yahoo.co.id
}

\begin{abstract}
Supporting of women's participation in politics is legitimated in the form of the Law No. 10 of 2008 on general elections members of the House of Representatives, Regional Representatives Council, and Regional House of Representative. The potential of women in parliament in the Karawang district only 6 seats. Which shows that the participation and election laws that give a quota of $30 \%$ has not been realized maximally. On the basis of these problems, the researcher is interested to carry out research into how the involvement of women in the legislative process with the title "Women's Political Participation in legislative process of Regional House of Representative at Karawang District Period 2009-2014".
\end{abstract}

Keywords- Politics, Gender, Legislative Process, Parliament

\section{INTRODUCTION}

Today the issue of gender is crucial, found some gender discrimination, especially in women in scope of social, occupational, or politics and government. Gender emerged from the 19th century until the early 20 s, so did in the 1970 s, women have made some gatherings such as Dharma Wanita, Perwari (Association of Women of the Republic of Indonesia), Posyandu, and others. Support the participation of women in politics is legitimate in the form of the Law No. 10 of 2008 on general elections members of the House of Representatives, Regional Representatives Council, and Regional House of Representative has implemented the principle of the application of the quota of $30 \%$ of the vote for women in parliament is also stymied.

The potential of women in parliament in the Karawang district only 6 seats. Which shows that the participation and election laws that give a quota of $30 \%$ has not been realized maximally. Both in terms of the legislative process as well as the number of its quota. Based on the background, it should be emphasized about the issues that will be discussed related to shift the old paradigm of women as human complement of men have become a source of discrimination in the realm of politics and legislation relating to the political involvement of women to the legislative process in
Parliament of Karawang district. Regional House of Representative has implemented the principles of $30 \%$ quota for women in parliament is also stymied, as seen from the data legislators Karawang District Period 2009-2014 as follows Tabel 1. From these data, we can see the potential of women in parliament, there are 6 seats. Which shows that the participation and election laws that give a quota of $30 \%$ has not been realized optimally. Both in terms of the legislative process as well as the number of its quota.

\section{RESEARCH METHOD}

This research used descriptive method with qualitative approach, because to answer how the involvement of women in the legislative process in Karawang district is required description of the engagement process with data collection, observation and interviews on informants, the informant is the Head Region of Court in Karawang district, Member of women parliament Karawang district.

The results showed that the Karawang district legislature seat placement is based on the majority vote system with the placement of candidates who have not applied zyper system, so the impact on the lack of women's chances of victory in the election. Therefore, women had a $12 \%$ quota of seats membership. Two categories of representation, namely political representatives and functional representatives, second category concerns the role of parliamentarians as bearers of a mandate is not running maximally.

Based on these descriptions researcher determine informants in this study are: Head Region of Court in Karawang district as Key informant, Three representatives of women members of parliament in Karawang, Three representatives of the male members of legislature in Karawang. Once the data is acquired, the data analysis used was initiated by the reduction of the data, the display presents the data and draw a conclusion. 


\section{RESULT FINDINGS AND DISCUSSION}

In general it can be said that politics is an assortment of activities within a political system (or state) concerning the process of defining the objectives of the system and implement the objectives that it is based on the assertion of decisions (decision making) to what objectives of the political system involved the selection among several alternatives and the development priorities of the objectives. Implementing of these objectives need to be determined policies (public policies) or allocation of resources and the existing resources [1].

Politics has always been related to the objectives of the whole society (public goals), and not one's personal goals (private goals). Besides politics concerning the activities of various groups, including political parties and the activities of an (individual). The state is an organization in a region that has the highest legal authority and is obeyed by the people.

Defines participation as: "The participation of a person both mentally and emotionally, and to contribute to the process of the formation of the decision mainly on the question of where the involvement of the person concerned in its responsibility to implement it"[2]. The purpose of the above quote is that this participation was not only conducted by implementation of policies but also given when the decision-making process by involving personally to the decision. Based on the terms of participation above, it can be concluded that: The mental and emotional involvement, so it is not limited to physical appearance; Supporting to do activities in a group setting, so people got the same opportunity to take the Initiative; The spirit existence of responsibility for a particular activity as a result of his involvement; Self-engagement means participating involvement of mind and emotion; Participation is not only limited to the process of implementation of the decisions also included the planning and control process.

Gender issues are crucial, found some gender discrimination, especially in women in the scope of social, occupational, or politics and government. The goal is to accelerate the achievement of justice and equality. One of the most important tools to implement the law, which guarantees the implementation should be in the Constitution and the Law.

Affirmative action for women can be assessed through three areas, namely politics, management, implementation as well zipper system. In the political field is reflected to oblige political parties to include a minimum of $30 \%$ representation of women in establisment as well as in the management at the central level. Affirmative action in the application zipper system. The system requires that every three candidates at least one is woman. As the above presentation, drawing framework of this paper is as follows:
The policy is a form of political involvement of women maximally as Law No. 10 of 2008 on the Election of Members of Parliament.

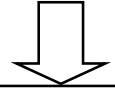

Parliament Functions According to

Law No. 32 of 2004

1. Legislation Function

2. Budget Function

3. Supervision Function

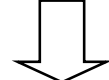

How the decision-making process of the Board of Representatives Karawang and extent of women's involvement in the legislative process in Karawang district based on policy view of affirmative action.

Figure 1. Framework

Researcher analyzed the forms of engagement is about $30 \%$ quota of legislative candidates are carried by each of the political party as those set forth by Law No. 10 Year 2008 regarding the General Election legislators and how the positioning of women's representation in Parliament of Karawang district.

Based on the data obtained from the interview with the head region of court Karawang district Bapak. Asep Baharudin, we get the following data in table 1 . And we can show the Representation of Women in Completion Tools of Regional House of Representative Period 2009-2014 in table 2. Based on data from Table 2 , showed that the number of members of Regional House of Representative period 2009-2014 was 50 people consisting of a number of men is 44 or $88 \%$ and women amounted to 6 people or $12 \%$. This is supported by the number of women's representation in Regional House of Representative Karawang are also experiencing a crisis of representation of women (Table 2).

Although the quota of $30 \%$ specified in the law is a form of quota representation of women nominated by each party. However, the implementation of seat placement for Regional House of Representative is based on the majority vote system with the placement of candidates who have not applied zyper system, so the impact on the lack of women's chances of victory in the elections. Therefore, women received $12 \%$ of the seats in parliament membership Kabupten Karawang. Therefore, it makes the representation of women's voices are considered not maximized. 
Table 1. Number of Seats Karawang District Period 2009-2014

\begin{tabular}{|c|l|c|c|c|}
\hline \multirow{2}{*}{ NO } & \multirow{2}{*}{ PARTY } & \multicolumn{2}{|c|}{$\begin{array}{c}\text { NUMBER } \\
\text { OF SEATS }\end{array}$} & \multirow{2}{*}{$\begin{array}{c}\text { OBTAINED } \\
\text { SEATS }\end{array}$} \\
\cline { 3 - 4 } & & MAN & WOMAN & \\
\hline 1 & HANURA & 2 & & 2 \\
\hline 2 & GERINDRA & 6 & & 6 \\
\hline 3 & PKS & 5 & 1 & 6 \\
\hline 4 & PAN & 1 & & 1 \\
\hline 5 & PKB & 3 & 1 & 4 \\
\hline 6 & GOLKAR & 8 & & 8 \\
\hline 7 & PPP & 1 & & 1 \\
\hline 8 & PBB & 1 & 2 & 3 \\
\hline 9 & PDI-P & 8 & 1 & 9 \\
\hline 10 & PBR & 1 & & 1 \\
\hline 11 & DEMOKRAT & 8 & 1 & 9 \\
\hline
\end{tabular}

Source: Secretariat of the Council Karawang District, 2013

Representation of women that occurs is still little when viewing the phenomenon. Although affirmative action is recognized in Indonesia with the enactment of Election Law No. 10 of 2008 regarding the nomination of women in legislative candidates, still in its implementation is not maximized. This happens either because not maximal recruitment conducted by the political parties for the nomination of women as well as the potential and desire of the women themselves who do not have the desire to be involved in Parliament. Or even, the paradigm of society which still cannot accept and assume taboo when women take participation in the political sphere.

Table 2. Representation of Women in Completion Tools of Regional House of Representative Period 2009-2014

\begin{tabular}{|c|c|c|c|}
\hline NO & MEMBERSHIP & $\begin{array}{c}\text { TOTAL } \\
\text { REPRESENTATION }\end{array}$ & $(\%)$ \\
\hline \multirow[t]{5}{*}{1.} & $\begin{array}{l}\text { membership of the } \\
\text { Commission }\end{array}$ & & \\
\hline & 1. Commission $\mathrm{A}$ & 2 people & $4 \%$ \\
\hline & 2. Commission B & - & $0 \%$ \\
\hline & 3. Commission $\mathrm{C}$ & 1 person & $2 \%$ \\
\hline & 4. Commission D & 4 people & $8 \%$ \\
\hline 2. & $\begin{array}{c}\text { Membership } \\
\text { Consultative board }\end{array}$ & 2 people & $4 \%$ \\
\hline 3. & $\begin{array}{c}\text { Keanggotaan Badan } \\
\text { Anggaran }\end{array}$ & 2 people & $4 \%$ \\
\hline 4. & $\begin{array}{c}\text { Keanggotaan Badan } \\
\text { Legislasi } \\
\end{array}$ & 1 person & $2 \%$ \\
\hline 5. & $\begin{array}{c}\text { Keanggotaan Badan } \\
\text { Kehormatan }\end{array}$ & 2 people & $4 \%$ \\
\hline
\end{tabular}

Source: Secretariat of the Council Karawang District, 2013
The one of interviewees Ibu Nurlelah Saripin told to researcher that: "The representation of women at the time the nomination is not only supposed to be. I believe every party must have run $30 \%$ of the quota, because if it is not, how the party can qualify in the Commission of General Election. However, when in the parliament whether she is active in giving initiative, I know for myself that very lack of potential for women who want to run for the legislature, once her wish but her husband does not allow. I still do not know, whether I am as a fulfillment of quotas or see my potential. But most of us are selected to be representative as requirement to pass selection in Ellection General Commission."

This is reinforced by statement of Bapak. H. Budiwanto, S.Si. MM, (Vice Chairman III Karawang): "The law does mention the existence of a quota of $30 \%$, but in reality the spirit of the law is not followed by a female spirit to become legislative candidates. And for the fulfillment of the $30 \%$ quota may be laws are still new at the time, so the implementation is not maximized. It is possible that only some political parties to meet the requirements of the General Ellection Commission"

Based on the statement above, it can be concluded that the political involvement of women is still not maximized when viewed in terms of quotas, as the concept of affirmative action in the General Election Law No. 10 of 2008 regarding the nomination of women in legislative candidates.

Regional House of Representative in general had three main functions, namely legislation, budgeting, and Controlling. In this case, the involvement of three closely connected in that function. Therefore, the legislative process will produce a public policy law as a product aimed at the welfare of society as fair. Public policy is the way to achieve common goals aspired [3]. If the ideals of the nation of Indonesia is to achieve fair and prosperous society based on Pancasila (Divinity, Humanity, Unity, Democracy and Justice) and 1945 (the Unitary Republic of Indonesia based on law and not merely power). Therefore, each element of the human being is entitled to equal rights in law and government. Thus, it is necessary that the Regional House of Representative there are representation of women in voicing the needs and improvement of marginal groups, in this case regarding the problems faced by women in particular.

Political involvement or in other words according Winardi political participation is the participation of a person both mentally and emotionally, and to contribute to the process of forming a decision, especially on the question of where the involvement of the person concerned in its responsibility to implement it. 
Therefore, to see the extent of political involvement of women in Regional House of Representative Karawang. Researcher viewed from several aspects, are not limited to physical appearance, the drive to support the activities and initiative, is responsible for a particular activity as a result of its involvement, and participated involvement thoughts and feelings. There are two categories of representation, namely political representation and functional representation. The second category concerns the role of Member of Parliament as a trustee, and his role as bearers of a "mandate" representation is the concept that one person or group has the ability or obligation to speak and act on behalf of a larger group [4].

The role and functions of Parliament are required to be able to contribute as a mouthpiece for the people. Therefore, the role of the initiative in delivering the aspirations of the people is an obligation that must be owned by every Member of Parliament. Not only reviewing the extent to which the presence of the members of parliament in following the policy making process, but also the extent to which our members' ability to deliver what it stands for. Moreover, the women legislators who rightly fight for women's rights.

As the statement of one of the women members of Regional House of Representative Karawang that researcher had encountered on Monday, October 27, 2014 Mumun Memunah, S.Si., Apt as a member of Commission A and representativeness of the PKS party. "The Parliament has a right of initiative, so with women represenation are efforted to think of things that are considered trivial relating to women. For example, when a flood, women who have ideas and proposals to priority needs of women. However, from several meetings that run, the most active issuing that opinion of 6 people, there are only 2 until 3 women [5].

Based on the exposure, the importance of women's representation in parliament is needed. Especially for marginal groups of women who often ruled out their needs. This was confirmed by the statement of one of the male legislators that researcher encountered on Thursday, November 6, 2014 Bapak. Dedi Sudrajat. "The representation of women in Parliament is very important, because there are some problems that can indeed be solved by women. Women are usually the approach closer to the heart of prudence compared with men who may never think"

However, to be considered is how the process of representation that can be run, if the women who are in Regional House of Representative less voicing and fighting for women's rights, the right of initiative it has not carried out to the maximum. This happened because by the readiness of some members of parliament that woman are able to sit in Parliament as well as the background of each member.
Based on the decision-making system, consisting of three processes, namely input, process and output. Formal model legislation process is the policy of "policy ideas", "formulation and legalization policy", "implementation", and then headed to the performance or achievement to be expected after the evaluation of policy performance [6]. Therefore, the results of which have gone through the process inputs and processes, the policiy aims to produce a decision. In this case, the council will produce local regulations during the tenure of the membership of Parliament [7].

Based on the data obtained, during the 5 years of management of Regional House of Representative in 2010 produced 8 regulations 2011 produced 12 regulations 2012 produced 18 regulations, in 2013 produced 12 regulations, and January 2014 resulted in three local regulations. However, when analyzed the results obtained regulations that shows gender concerns are approximately 3 regulations, including regulation No. 1 of 2011 concerning employment, regulation No. 8 of 2012 which is providing social welfare, Regulation No. 18 of 2012 on the placement and protection of migrant workers, and some regulations still have gender bias.

Based on interviewee statement, there are some regulations concerning the representation of women, among others "Examples of existing regulations, the local regulations at the time of employment, because of the time it was more populer the demands of women workers who asked their rights, such as menstruation and childbirth. It was one of our struggle. There are also about migrant workers and human trafficking, it needs to be studied because the majority of victims are women" Although some of the regulations concerning the regulations on women have been made, but they are still bias and not completely fight for the women problems.

\section{CONCLUSION}

Political involvement of women in Regional House of Representative Karawang is still not maximum both in terms of quotas and the process of legislation and legal products are produced. Though essentially political involvement of women not only have to meet a quota but how the representation can produce a policy which fulfill needs for women.

The implication that women's representation in Regional House of Representative in Karawang increase both in terms of quotas and the legislative process, the researcher recommend: Keep the firmness of the Law no. 10 of 2008 on general elections in particular clause 53 and 55 paragraph 2, Each political party must prepare cadres of women members who nominate or be nominated. So that prospective women members who will sit in the seat of Parliament is not only fulfill the quota but has quality in carrying out its duties and functions, It should be increased one political party function of providing political education to the community in order to have new insight of society and changing patriarchy cultural paradigm. 


\section{REFERENCES}

[1] Keith Davis . 1991. "Perkembangan Pemerintahan di Daerah". Penerbit Liberty : Yogyakarta.

[2] Winardi.1989."Perencanaan dan Pengawasan dalam Bidang Manajemen". CV Mandar Maju : Bandung.

[3] Nugroho, Riant. 2011. “ Public Policy”. PT. Gramedia: Jakarta
[4] Budiardjo, Miriam. 2009. "Dasar-dasar Ilmu Politik”. PT. Gramedia Pustaka Utama : Jakarta.

[5] Sjamsuddin, Nazarudin.1988."Sistem Politik Indonesia" Modul UT. PT.Karunika Jakarta : Jakarta.

[6] Sugiyono. 2008. "Metode Penelitian Pendidikan Pendekatan Kualitatif, Kuantitatif, dan R\&D”. CV.Alfabeta: Bandung.

[7] Sukarna. 1990. "Sistem Politik". PT Citra Aditya Bakti : Bandung. 